\section{References}

1 Vannas, S, and Orma, H, Archives of Ophthalmology, 1957, 58, 812.

${ }^{2}$ Hiemeyer, V, Deutsche medizinische Wochenschrift, 1967, 92, 955.

3 Ottolander, G J H, and Craandijk, A, Thrombosis et Diathesis Haemorrhagica, 1968, 20, 415 .

${ }^{4}$ Rossman, H, Postgraduate Medical fournal, 1973, 49, suppl (August), p 105.

5 Dacie, J V, and Lewis, S M, Practical Haematology. London, Churchill, 1968.

${ }^{6}$ Ratnoff, O D, and Menzie, C, Fournal of Laboratory and Clinical Medicine, $1951,37,316$.
' Alkjaersig, N, Fletcher, A P, and Sherry, S, fournal of Clinical Investigation, 1959, 38, 1086 .

${ }^{8}$ Merskey, C, Kleiner, G J, and Johnson, A J, Blood, 1966, 28, 1.

${ }^{9}$ Joplin, G F, et al, Diabetologia, 1967, 3, 406.

10 Snedecor, G W, and Cochran, W G, Statistical Methods, 4th edn, p 236. Iowa State University Press, 1969.

${ }^{11}$ Klien, B A, and Olwin, J H, Archives of Ophthalmology, 1956, 56, 207.

12 Ancel, B, personal communication.

13 Laatikeinen, L, and Kohner, E M. In press.

${ }^{14}$ Cash, J D, British Medical fournal, 1969, 2, 502.

15 Sawyer, W D, et al, fournal of Clinical Investigation, 1960, 39, 426.

16 Ogston, D, and Fullerton, H, Lancet, 1961, 2, 730.

\title{
Islet-cell, thyroid, and gastric autoantibodies in diabetic identical twins
}

\author{
R LENDRUM， P G NELSON, D A PYKE, G WALKER, D R GAMBLE
}

British Medical fournal, 1976, 1, 553-555

\section{Summary}

Sera from 54 pairs of identical twins, 29 discordant and 25 concordant for insulin-dependent diabetes, and 11 pairs of concordant non-insulin dependent identical twins were examined for pancreatic islet-cell antibodies (ICAs). ICAs were found in 10 of the 29 diabetic discordant and eight of the 50 concordant twins (difference not significant $P>0 \cdot 05$ ). Six out of nine twins tested within one year of onset of diabetes were positive, whereas nine out of 29 tested after one to 10 years and three out of 41 tested after 10 years were positive. Only one of the 22 non-insulin-dependent twins had ICAs. Repeat ICA testing in five pairs of insulin-dependent twins and in the siblings of one pair showed that ICAs may be present in people with normal glucose tolerance; may precede clinical diabetes by several years; and may decline in titre or disappear with increasing duration of disease.

Thyroid or gastric autoantibodies, or both, were found in 36 out of 108 insulin-dependent twins and three out of 22 non-insulin dependent twins (difference not significant $P>0.05)$. Only four twins had both ICAs and thyrogastric antibodies. There were no significant associations between autoantibodies and HLA histocompatibility types.

As ICAs are more common in the diabetic than the non-diabetic twins of the discordant pairs they must be associated with juvenile onset diabetes. ICAs may appear some years before the onset of diabetes, but their prevalence declines with increasing duration of diabetes. The factors determining the production of ICA differ from those for thyroid and gastric autoantibodies.

Department of Gastroenterology, St Mary's Hospital, London W2 $R$ LENDRUM, MRCP, research fellow

G WALKER, FRCP, consultant physician

Diabetic Department, King's College Hospital, London SE5 9RS P G NELSON, MRCP, research fellow

D A PYKE, FRCP, consultant physician

Public Health Laboratory, West Park Hospital, Epsom, Surrey D R GAMBLE, FRCPATH, director

\section{Introduction}

Humoral autoimmunity directed against pancreatic islets ${ }^{1}{ }^{2}$ occurs in about half of newly diagnosed diabetic children. ${ }^{3}$ The relative importance of genetic and environmental factors in the production of these antibodies is not known. In a recent study of insulin-dependent diabetic identical twins ${ }^{4}$ one-half were concordant (both twins diabetic) and the remainder discordant (only one twin affected). While it is now thought that there is genetic susceptibility to diabetes in both groups, since both discordant and concordant pairs show certain HLA associations, ${ }^{5}$ environmental factors must also be implicated in the aetiology of diabetes in the discordant pairs.

In an attempt to determine the importance of autoimmunity in the aetiology of insulin-dependent diabetes we tested identical twins for the presence of islet-cell antibodies (ICAs). We also tested the twins for thyrogastric autoantibodies.

\section{Patients and methods}

The identical twins were part of a larger series described elsewhere. ${ }^{4}$ Stored serum samples were examined from: 29 twin pairs discordant for insulin-dependent diabetes and 25 twin pairs concordant for insulin-dependent diabetes. In both groups the mean age at diagnosis was 20 years. Repeat samples were obtained from one concordant and four discordant pairs, and sera from two non-diabetic sibs of the concordant pair were also tested. Samples from 11 noninsulin-dependent twin pairs with maturity onset diabetes all of whom were concordant were also examined. Their mean age at diagnosis was 60 years.

Clinical details appear in table I. The non-diabetic twins in the discordant pairs were studied for up to nine years and all have had at least one (and in most cases several) oral glucose tolerance test, the results of which have all been within the normal range.

TABLE I-Clinical features of twins at time of testing

\begin{tabular}{|c|c|c|c|c|}
\hline Pair types & Co-twins & $\begin{array}{c}\text { Mean } \\
\text { age } \\
\text { (and) } \\
\text { range) } \\
\text { (years) }\end{array}$ & $\begin{array}{c}\text { Mean } \\
\text { duration of } \\
\text { diabetes } \\
\text { (and } \\
\text { range) } \\
\text { (years) }\end{array}$ & $\begin{array}{c}\text { No of pairs } \\
\text { with } \\
\text { history } \\
\text { of diabetes } \\
\text { in 1st degree } \\
\text { relative }\end{array}$ \\
\hline $\begin{array}{l}\text { Discordant insulin- } \\
\text { dependent } \\
\text { (29 pairs: } 11 \mathrm{M}, 18 \mathrm{~F} \text { ) }\end{array}$ & $\begin{array}{l}\text { Diabetic } \\
\text { Non-diabetic }\end{array}$ & $\begin{array}{c}29 \\
(7-62) \\
29 \\
(7-62)\end{array}$ & $\begin{array}{cc}9 \cdot 4 \\
(1 \text { month-29) }\end{array}$ & 3 \\
\hline $\begin{array}{l}\text { Concordant insulin- } \\
\text { dependent } \\
\text { ( } 25 \text { pairs: } 11 \mathrm{M}, 14 \mathrm{~F})\end{array}$ & $\begin{array}{l}\text { 1st diagnosed } \\
\text { 2nd diagnosed }\end{array}$ & $\begin{array}{c}34 \\
(10-66) \\
34\end{array}$ & $\begin{array}{l}15 \cdot 7 \\
(1-44) \\
12 \cdot 2\end{array}$ & 6 \\
\hline $\begin{array}{l}\text { Concordant non-insulin- } \\
\text { dependent } \\
\text { (11 pairs: } 6 \mathrm{M}, 5 \mathrm{~F} \text { ) }\end{array}$ & $\begin{array}{l}\text { 1st diagnosed } \\
\text { 2nd diagnosed }\end{array}$ & $\begin{array}{c}67 \\
(57-81) \\
67 \\
(57-81)\end{array}$ & $\begin{array}{c}8 \cdot 6 \\
(3 \text { months-22) } \\
6 \cdot 7 \\
(0-23)\end{array}$ & \} \\
\hline
\end{tabular}


Immunofluorescent methods-ICAs were detected by methods previously described, ${ }^{6}$ except that undiluted serum was applied to pancreas sections for 40 instead of 20 minutes; this gave stronger fluorescence with positive sera without producing positive results in control sera. ${ }^{3}$ Sheep antihuman whole immunoglobulin (Wellcome Laboratories) was the second layer in all tests. For detecting thyroid microsomal and gastric parietal-cell antibodies undiluted serum was applied for 20 minutes. All tests were carried out on randomly assorted sera without knowledge of the clinical details or the twin relationships of the patients. Positive results were confirmed in at least two tests. Titres were measured in serial doubling dilution, beginning at $1 / 2$.

\section{Results}

\section{SERUM AUTOANTIBODIES}

\section{Islet-cell antibodies}

Islet-cell antibodies (ICA) were present in 18 of the 79 insulindependent diabetic twins- 10 of the 29 discordant and eight of the 50 concordant twins (difference not significant; $P>0.05$ ) (table II). In three of the 29 discordant pairs both the diabetic and non-diabetic co-twins were ICA-positive: these pairs had been discordant for five months, two years, and 11 years. In the concordant pairs the seconddiagnosed twin alone was positive in four pairs and both first and second diagnosed were positive in two.

TABLE II-Details of insulin-dependent twins positive for islet-cell antibodies

\begin{tabular}{|c|c|c|c|c|c|}
\hline \multirow{2}{*}{$\begin{array}{l}\text { Pair } \\
\text { No }\end{array}$} & \multicolumn{2}{|c|}{ ICA titre in: } & \multirow{2}{*}{\multicolumn{2}{|c|}{$\begin{array}{l}\text { Duration } \\
\text { of diabetes } \\
\text { (years) }\end{array}$}} & \multirow{2}{*}{$\begin{array}{l}\text { Age at } \\
\text { at testing } \\
\text { (years) }\end{array}$} \\
\hline & $\begin{array}{c}\text { Diabetic } \\
\text { twin }\end{array}$ & $\begin{array}{c}\text { Non-diabetic } \\
\text { twin }\end{array}$ & & & \\
\hline \multicolumn{6}{|c|}{ Discordant pairs $(n=29)$} \\
\hline $\begin{array}{r}1 \\
2 \\
3 \\
4 \\
5 \\
6 \\
7 \\
8 \\
9 \\
10\end{array}$ & $\begin{array}{l}1 / 16 \\
1 / 8 \\
1 / 8 \\
1 / 4 \\
1 / 4 \\
1 / 4 \\
1 / 4 \\
1 / 4 \\
1 / 2 \\
1 / 2\end{array}$ & $\begin{array}{c}1 / 8 \\
1 / 8 \\
0 \\
1 / 16 \\
0 \\
0 \\
0 \\
0 \\
0 \\
0\end{array}$ & & $\begin{array}{l}5 \text { months } \\
11 \\
6 \text { months } \\
2 \\
5 \\
5 \\
1 \frac{1}{2} \\
6 \text { months } \\
15 \\
3 \text { months }\end{array}$ & $\begin{array}{r}17 \\
16 \\
13 \\
14 \\
23 \\
9 \\
15 \\
20 \\
51 \\
28\end{array}$ \\
\hline \multicolumn{6}{|c|}{ Concordant pairs $(n=25)$} \\
\hline & 1st diagnosed & 2nd diagnosed & 1st twin & 2nd twin $\mid$ & \\
\hline $\begin{array}{l}11 \\
12 \\
13 \\
14 \\
15 \\
16\end{array}$ & $\begin{array}{r}1 / 16 \\
1 / 8 \\
0 \\
0 \\
0 \\
0\end{array}$ & $\begin{array}{l}1 / 2 \\
+* \\
1 / 8 \\
1 / 4 \\
1 / 2 \\
1 / 2\end{array}$ & $\begin{array}{c}10 / 12 \\
3 \\
18 \\
34 \\
12 \\
12\end{array}$ & $\begin{array}{c}9 \text { mths } \\
15 \text { mths } \\
9 \\
25 \\
8 \\
9\end{array}$ & $\begin{array}{l}15 \\
10 \\
28 \\
63 \\
66 \\
31\end{array}$ \\
\hline
\end{tabular}

*Insufficient serum to measure titre.

The number of twins who were ICA positive declined with increasing time after diagnosis (table III). Of those tested within five years of diagnosis 12 out of 23 were positive but of those tested later only six out of 55. Eight of 11 discordant and four out of 12 concordant twins tested within five years of the onset of diabetes were ICA positive; this difference was not significant. The mean duration of diabetes was significantly less in ICA-positive (five years) than in ICAnegative twins (14 years). In contrast to the common finding of ICAs in the insulin-dependent twins, these antibodies were detected in only one of the 22 people with maturity onset diabetes, although 13 were tested within five years of onset.

Second serum samples were tested in one concordant and four discordant pairs after periods of six months to three and a half years. These five case histories are summarised below.

Pair No 2 (female, discordant)-The index twin developed insulindependent diabetes at the age of 5 years. When first tested 11 years later the serum of both twins was ICA positive at a titre of $1 / 8$. ICAs were still

TABLE III-Number of diabetic twins with islet-cell antibodies in relation to duration of diabetes

\begin{tabular}{|c|c|c|c|c|}
\hline Duration of diabetes (years): & $<1$ & $1-5$ & $6-10$ & $>10$ \\
\hline 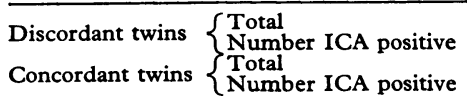 & $\begin{array}{l}5 \\
4 \\
4 \\
2\end{array}$ & $\begin{array}{l}6 \\
4 \\
8 \\
2\end{array}$ & $\begin{array}{l}6 \\
0 \\
9 \\
3\end{array}$ & $\begin{array}{r}12 \\
2 \\
29 \\
1\end{array}$ \\
\hline
\end{tabular}

detectable at the same titre in both twins 18 months later; the non-diabetic co-twin had normal glucose tolerance on both occasions.

Pair No 4 (female, discordant) - The affected co-twin developed insulinrequiring diabetes in September 1971, when she was 12 . Serum samples obtained from both co-twins two years later were ICA-positive at titres of $1 / 4$ in the diabetic and $1 / 16$ in the non-diabetic. In the unaffected twin blood glucose and insulin responses to oral glucose and intravenous tolbutamide were normal. Four years after the diagnosis of diabetes the diabetic became ICA negative and the non-diabetic remained positive at titre of $1 / 16$. Oral glucose tolerance in the non-diabetic has not deteriorated.

Pair No 7 (female, discordant)-Eighteen months after the onset of insulin-requiring diabetes at the age of 13 years the diabetic twin was ICA positive at a titre of $1 / 4$; this titre was unchanged six months later. The nondiabetic twin was ICA negative on both occasions.

Pair No 8 (male, discordant)-Symptomatic diabetes developed in March 1971 at the age of 20 years and was controlled with oral treatment until January 1973, when insulin treatment was started. ICAs were not detected in either co-twin one month after the diagnosis of diabetes but were present in the diabetic twin six and 10 months later at titres of $1 / 4$ and $1 / 2$ respectively.

Pair No 11 (female, concordant)-The first twin developed insulinrequiring diabetes in October 1970, at the age of 14 years. One month later the second twin, although asymptomatic, had an abnormal glucose tolerance curve. She was initially treated with diet alone, to which a sulphonylurea was later added. In January 1972 she developed diabetic symptoms and insulin was started. In August 1971 ICA titres in the first and second-diagnosed twins were $1 / 16$ and $1 / 2$ respectively but on retesting in March 1975 they had become respectively $1 / 2$ and nil. Serum was obtained from two nondiabetic sibs of this pair at the time of first testing in 1971. ICAs were detected in both sera, at titres of $1 / 32$ and $1 / 1$. The sib with the higher titre became an insulin-requiring diabetic in January 1975, three and a half years after the first test.

These pairs show that ICAs may (a) be present in people with normal glucose tolerance, $(b)$ precede clinical diabetes by as much as three and a half years, and $(c)$ decline in titre or disappear with increasing duration of disease.

\section{Thyroid microsomal and gastric parietal-cell antibodies}

Among 108 people from the 25 concordant and 29 discordant pairs thyroid antibodies were detected in 27 (eight non-diabetics) and gastric parietal-cell antibodies in 20 (five non-diabetics). They occurred together in 11 twins, and thus thyroid or gastric antibodies were present in 36 of the 108 subjects ( 17 out of 58 discordant and 19 out of 50 concordant). One or both of these antibodies were present in both co-twins of six discordant and six concordant pairs. Discordant twins with thyrogastric antibodies were significantly older than those without (mean ages 37 and 27 years respectively); there was no correlation with the duration of diabetes in either group. Of the 17 positive discordant twins 16 were female, compared with only nine of the 19 positive concordant twins. Thyroid or gastric antibodies, or both, occurred in only three of the 22 non-insulin-dependent twins.

The difference in prevalence of thyroid and gastric antibodies in the insulin-dependent (36 out of 108) and non-insulin-dependent twins (three out of 22) was not significant $(P>0.05)$. Thyroid or gastric antibodies co-existed with ICAs in only four people (both co-twins of one discordant pair and two unrelated concordant twins).

\section{HISTOCOMPATIBILITY ANTIGENS IN INSULIN-DEPENDENT TWINS}

HLA tissue types were known in 52 of the 54 insulin-dependent twin pairs (table IV). There were no significant associations between specific HLA antigens and the presence of autoantibodies but W 15 antigens were more prevalent among ICA-positive discordant diabetic twins ( 6 out of 10) than among those who were ICA-negative (5 out of 19). HLA 8 also tended to be more common in patients with

TABLE IV-Prevalence of $H L A-8$ and $W 15$ antigens among 75 diabetic twins positive and negative for autoantibodies. Results are numbers of patients

\begin{tabular}{|c|c|c|c|c|c|c|c|c|c|}
\hline & \multicolumn{3}{|c|}{ Concordant twins } & \multicolumn{3}{|c|}{ Discordant twins } & \multicolumn{3}{|c|}{ All twins } \\
\hline & Total & HLA-8 & W15 & Total & HLA-8 & W 15 & Total & HLA-8 & W 15 \\
\hline $\begin{array}{l}\text { ICA positive } \\
\text { ICA negative }\end{array}$ & $\begin{array}{r}8 \\
38\end{array}$ & $\begin{array}{r}2 \\
18\end{array}$ & $\begin{array}{r}4 \\
18\end{array}$ & $\begin{array}{l}10 \\
19\end{array}$ & $\begin{array}{l}2 \\
5\end{array}$ & $\begin{array}{l}6 \\
5\end{array}$ & $\begin{array}{l}18 \\
57\end{array}$ & $\begin{array}{r}4 \\
23\end{array}$ & $\begin{array}{l}10 \\
23\end{array}$ \\
\hline $\begin{array}{l}\text { Thyrogastric } \\
\text { positive } \\
\text { Thyrogastric } \\
\text { negative }\end{array}$ & $\begin{array}{l}19 \\
27\end{array}$ & $\begin{array}{l}10 \\
10\end{array}$ & $\begin{array}{r}9 \\
13\end{array}$ & $\begin{array}{r}8 \\
21\end{array}$ & $\begin{array}{l}3 \\
4\end{array}$ & $\begin{array}{l}2 \\
9\end{array}$ & $\begin{array}{l}27 \\
48\end{array}$ & $\begin{array}{l}13 \\
14\end{array}$ & $\begin{array}{l}11 \\
22\end{array}$ \\
\hline
\end{tabular}


thyrogastric antibodies (13 out of 27) than in those without (14 out of 48).

\section{Discussion}

A high prevalence of ICAs in insulin-dependent diabetics is confirmed by this study of identical twins. The prevalence of ICAs in the twin pairs is related to the duration of their diabetes: of the nine twins tested within a year of onset of diabetes six were ICA-positive, a figure comparable with that for other patients with juvenile onset diabetes. ${ }^{3}$ The observation that the prevalence of ICAs declines with increasing duration of disease is supported by serial findings in three twins: in two they had disappeared and in the third the titre had decreased at the second test. These findings accord with our unpublished results in a larger series of insulin-dependent diabetics in whom antibody prevalence decreased to less than $20^{\circ}$ o three or more years after diagnosis. There were no features (sex, family history, abruptness of onset of diabetes or its severity, concordance or discordance for diabetes, the presence of thyrogastric antibodies or specific HLA types) to distinguish the 10 twins in whom ICAs were detected two or more years after the onset of diabetes from ICA-negative twins with the same duration of diabetes.

Previous studies of these twins have suggested that the diabetes in the concordant and discordant pairs may have different causes. ${ }^{4}$ The prevalence of the histocompatibility antigen HLA-8 is increased in concordant but not in discordant pairs, while the prevalence of W 15 is increased in both. ${ }^{5}$ Antibodies to Coxsackie $\mathrm{B}_{2}$ virus, rubella virus, and Mycoplasma pneumoniae are present more often in discordant than in concordant twins. ${ }^{7}$ In the present study 16 of the 17 discordant twins with thyrogastric antibodies were female, compared with only 9 of the 19 concordant twins, which again suggests a possible difference between these two groups.

ICAs were commoner in the affected member of discordant twins ( 10 out of 29 ) than in concordant twins ( 8 out of 50 ). Although part of the difference can be attributed to the longer duration of diabetes in the concordant pairs a difference still remains among those twins tested within five years of diagnosiseight out of 11 discordant twins were ICA-positive compared with only four out of 12 concordant twins-which may be another reflection of a differing pathogenesis in the discordant and concordant pairs.

The high prevalence of thyroid and gastric antibodies in the twins agrees with findings in other studies of diabetics. ${ }^{8-11}$ There was a poor correlation between the presence of thyrogastric antibodies and the presence of ICAs, only four people having both. This suggests that different factors govern the production of these two types of antibodies. Discordance for thyrogastric antibodies in some identical twin pairs supports the concept of an environmental factor in their production. ${ }^{12}$

The lack of association between specific HLA types and isletcell antibodies was not altogether surprising. Since the prevalence of ICAs decreased with duration of diabetes ICAs may have disappeared from the serum of many of the twins by the time we tested them. Unless a particular HLA antigen was associated with a persistence of ICAs no correlation would be expected. The slight increase in HLA-8 in diabetics with thyrogastric antibodies is interesting, as the frequency of this antigen is also increased in Graves' ${ }^{13}$ and Addison's ${ }^{14}$ diseases.

It is not known if overt diabetes is an invariable sequel to the presence of ICAs. The development of clinical diabetes in a sibling of a twin pair three and a half years after the finding of
ICAs at a titre of $1 / 32$ and the progression of chemical to insulindependent diabetes in two other ICA-positive twins suggests that progression to overt disease may be delayed. It will be of interest to follow the progress of the three ICA-positive non-diabetic twins. All have had recent glucose tolerance tests with normal results five months, four years, and 13 years after diabetes was diagnosed in their co-twins. Since in $70 \%$ of concordant pairs the second twin develops diabetes within four years of the first, ${ }^{4}$ only the last of these three non-diabetic twins seems to be outside the high-risk period.

Whether ICAs cause $\beta$-cell damage or result from it remains uncertain. That only one of the non-insulin-dependent twins with maturity onset diabetes was ICA-positive suggests that these antibodies are not important in that type of diabetes. Previous studies of insulin-dependent and non-insulin-dependent diabetes with respect to inheritance ${ }^{15}$ and prevalence of thyrogastric antibodies, ${ }^{8}$ virus antibodies, ${ }^{16}$ and HLA types ${ }^{17}$ support the concept that they are different diseases.

Our findings therefore suggest that (a) the more frequent finding of ICAs in the diabetic than in the non-diabetic members of discordant pairs of twins shows that ICAs are associated with juvenile onset, insulin-dependent diabetes; $(b)$ diabetic members of discordant pairs are more often ICA positive than concordant diabetic twins; (c) insulin-dependent diabetic twins do not differ from other insulin-dependent diabetics with respect to ICAs or thyrogastric autoantibodies; (d) ICAs may precede diabetic symptoms by several years but we do not know whether they always do so or whether they are always followed by diabetes; (e) ICAs are often present at or soon after the clinical onset of insulin-dependent diabetes, but their prevalence decreases thereafter; $(f)$ the factors that govern ICA production are distinct from those determining the production of thyroid and gastric autoantibodies; and $(g)$ ICAs are rarely found in non-insulin dependent diabetics and probably play no part in the aetiology of that type of diabetes.

We thank Professor D Doniach for helpful discussions, $\mathrm{Mr}$ Granville Swana for specimens of thyroid and stomach, Mr D Will for expert technical help and Mr A E Rippon for administrative help. PGN is supported by the Nuffield Foundation. We are indebted to Professor H A F Dudley, Mr M Snell, and Mr R F P Copland for making available pancreatic tissues.

Requests for reprints should be addressed to Dr $\mathrm{R}$ Lendrum St Mary's Hospital, London W2.

\section{References}

1 Bottazzo, G F, Florin-Christensen, A, and Doniach, D, Lancet, 1974, 2, 1279.

${ }^{2}$ MacCuish, A C, et al, Lancet, 1974, 2, 1529.

3 Lendrum, R, Walker, G, and Gamble, D R, Lancet, 1975, 1, 880.

4 Tattersall, R B, and Pyke, D A, Lancet, 1972, 2, 1120.

5 Nelson, P G, et al, Lancet, 1975, 2, 193.

6 Lendrum, R, and Walker, G, Gut, 1975, 16, 365.

7 Nelson, P G, Pyke, D A, and Gamble, D R, British Medical fournal, 1975, 4, 249.

${ }^{8}$ Irvine, W J, et al, Lancet, 1970, 2, 163.

9 Landing, B H, et al, fournal of Clinical Endocrinology and Metabolism, 1963, 23, 119.

10 Whittingham, S, et al, Lancet, 1971, 1, 763.

11 Nerup, J, and Binder, C, Acta Endocrinologica (København), 1973, 72, 279.

12 Buchanan, W W, et al, Annals of the Rheumatic Diseases, 1966, 25, 463.

13 Grumet, C, et al, Clinical Research, 1973, 21, 493.

14 Platz, P, et al, Lancet, 1974, 2, 289.

15 Tattersall, R B, and Fajans, S S, Diabetes, 1975, 24, 44.

${ }^{16}$ Gamble, D R, et al, British Medical fournal, 1969, 3, 627.

17 Nerup, J, et al, Lancet, 1974, 2, 864. 